\title{
有機溶媒電解液中でのマグネシウムの電気化学的挙動
}

\author{
吉本 信子*, 石川 正司*, 森田 昌行*

\section{Electrochemical Behavior of Magnesium in Organic Electrolyte Solutions}

\author{
Nobuko YOSHIMOTO*, Masashi ISHIKAWA* and Masayuki MORITA*
}

Key Words : Magnesium, Organic Electrolyte Solutions, Electrodeposition

\section{1. 緒言}

マグネシウム $(\mathrm{Mg})$ は卑な標準電極電位 $(-2.375 \mathrm{~V} v s$. $\mathrm{RHE})$, 低い当量 $(12.15 \mathrm{~g} / \mathrm{eq})$ を持ち, 軽量かつ安価で 資源的にも豊富であるばかりでなく, 取り扱いのうえで 比較的安全な金属であるので, 大型二次電池のための新 規材料として期待される金属である。また, $\mathrm{Mg}$ は電気 化学的に活性であるので, $\mathrm{Mg}$ 金属や $\mathrm{Mg}$ 合金を簡単に 電析できれば小塊の電鋳など表面処理の方面でも役立つ ものと考えられる。しかし Mg の持つ卑な標準電極電 位は, 電析を行う上では取り扱いの簡単な水溶液系浴を 使用できないという難点を抱えている。 Mg や Mg 合金 の電析に非水媒体を使用する試みは古くから行われてい るが, 報告例は少ない昼 3)。著者らはこれまでに新規な 機能性材料の開発を目的として, 有機電解液からの希土 類元素含有薄膜の電析プロセスについて研究してき た (4) 7)。その結果から類推して, $\mathrm{Mg}$ の電析には溶媒な らびに電解質塩の選択・組み合わせが重要であると考え られる。本研究では有機電解液から $\mathrm{Mg}$ あるいは $\mathrm{Mg}$ 合金をカソード基板上に電析させるための基礎的知見を 得ることを目的として, 溶媒に非プロトン性極性溶媒の $\mathrm{N}, \mathrm{N}-$ ジメチルホルムアミド (DMF)を使用し, $\mathrm{Mg}$ の DMF 中での電気化学的挙動を, 主としてサイクリック ボルタンメトリーにより検討した。

\section{2. 実験方法}

有機電解液の溶媒には, モレキュラーシーブス (4 A 1/16, 石津製薬(侏)，24 時間, $180^{\circ} \mathrm{C} て ゙$ 真空乾燥)で 脱水処理した DMF (石津製薬(秝)：スペクトル用)を使用 した。電解質塩には, 過塩素酸マグネシウム $(\mathrm{Mg}$ $\left(\mathrm{ClO}_{4}\right)_{2}$, 石津製楽(侏): 特級試薬), トリフルオロメタン スルホン酸マグネシウム $\left(\mathrm{Mg}\left(\mathrm{CF}_{3} \mathrm{SO}_{3}\right)_{2}\right.$, 森田化学工業 (侏)またはビス(トリフルオロメチルスルホニル)イミド マグネシウム $\left(\mathrm{Mg}\left[\left(\mathrm{CF}_{3} \mathrm{SO}_{2}\right)_{2} \mathrm{~N}\right]_{2}\right.$, セントラル硝子(侏)

*山口大学 工学部 (†755-8611 山口県宇部市常盤台 2-16-1)

Fac. of Eng., Yamaguchi Univ. (2-16-1, Tokiwadai, Ubeshi, Yamaguchi 755-8611)
を使用した。これらの電解質塩をそのまま，あるいは真 空乾燥したものを DMFに溶解して電解液とした。

溶媒および電解液の含水量は, カールフィッシャ水分 計(京都電子工業(侏)：MKC-3 p) を用いて測定した。

電解液の伝導度は, Kraus型のセルを使用し, $-10^{\circ} \mathrm{C}$ から $+50^{\circ} \mathrm{C}$ 範囲で LCR メーター (ANDO : AG -4311)により交流法 $(10 \mathrm{KHz}$ )で測定した。

電気化学測定にはビーカー型セルを用い, カソード (試験極)とアノード (対極)にはそれぞれ $10 \mathrm{~mm} \times 6 \mathrm{~mm}$, $120 \mathrm{~mm} \times 6 \mathrm{~mm}$ の $\mathrm{Mg}$ リボン(石津製薬(侏):特級)を使 用した。また, $\mathrm{Ag} / \mathrm{Ag}^{+}\left(0.01 \mathrm{~mol} \mathrm{dm} \mathrm{dm}^{-3} \mathrm{AgClO}_{4} / \mathrm{DMF}\right)$ を参照極として使用した。

電解液の調製, ならびにセルの組み立ては, 窒素雾囲 気下のドライボックス中で行った。すべての実験は室温 下で行った。電気化学測定には主としてサイクリックボ ルタンメトリーを用いた。

\section{3. 結果と考察}

電解液の電気伝導率を測定することは実用的な電解液 を設計するうえで重要であるばかりでなく, 溶液のイオ ン構造を推定する手がかりともなる。図 1 に, $0.5 \mathrm{M}$ $\mathrm{MgX}_{2}\left(\mathrm{X}=\mathrm{ClO}_{4}, \mathrm{CF}_{3} \mathrm{SO}_{3},\left(\mathrm{CF}_{3} \mathrm{SO}_{2}\right)_{2} \mathrm{~N}\right)$ を溶解した DMFのイオン伝導度の温度依存性を示す。カール フィッシャ水分計により測定した脱水処理後の DMF の 水分量は約 $70 \mathrm{ppm}$ であったので,この図に示した各電 解液の含水量はそれぞれの電解質塩に由来するものであ ると考えられる。 $\mathrm{b}, \triangle$, $\Delta$ は各電解質塩をそれぞれ所 定の温度で 8 時間から 12 時間真空乾燥した後に調製し た電解液のイオン伝導度である。各電解質塩により含水 量の差が大きく現れたが, 真空乾燥していない $\mathrm{Mg}\left(\mathrm{ClO}_{4}\right)_{2}$ 塩を溶解した電解液(含水量約 $1.1 \%$ )を除 いて伝導度に大きな相違は見られなかった。

一般に有機電解液の伝導度を測定する場合, 混入水分 の影響が非常に大きいと言われているが, 本実験で使用 した $\mathrm{Mg}$ 塩の場合, 真空乾燥時の条件や, その後の取 り扱い・保存方法との関連で, 含水量を一定にして電解 液を調製することはかなり困難であった。その中でも乾 


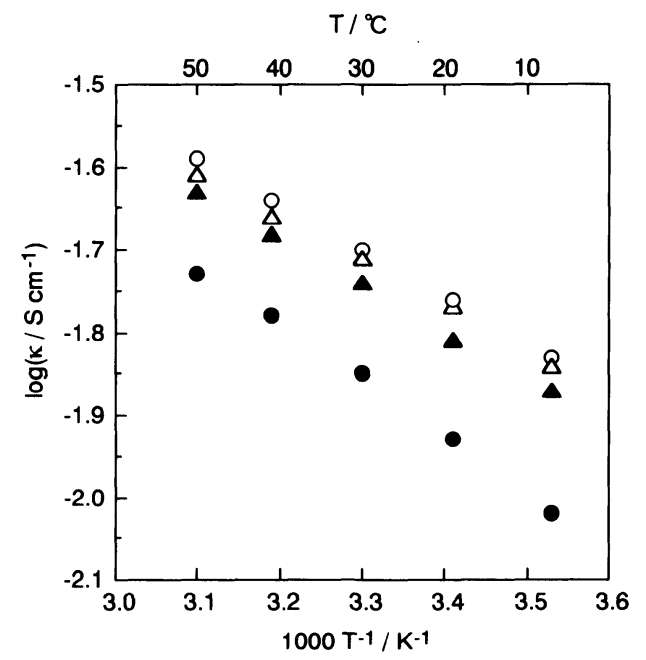

Fig. 1 Temperature dependence of ionic conductivity for DMF containing $\mathrm{MgX}_{2}$.

$\mathrm{O}: \mathrm{Mg}\left(\mathrm{ClO}_{4}\right)_{2}$ (water content ; $6000 \mathrm{ppm}$ ),

: $\mathrm{Mg}\left(\mathrm{ClO}_{4}\right)_{2}(11000 \mathrm{ppm})$,

$\triangle: \mathrm{Mg}\left(\mathrm{CF}_{3} \mathrm{SO}_{3}\right)_{2}(160 \mathrm{ppm})$,

$\Delta:\left(\mathrm{Mg}\left[\left(\mathrm{CF}_{3} \mathrm{SO}_{2}\right)_{2} \mathrm{~N}\right]_{2}(300 \mathrm{ppm})\right.$

燥後の水分含有量が一番少なく保存性にも優れており， 電解液の水分を制御することが比較的容易であったのは, $\mathrm{Mg}\left(\mathrm{CF}_{3} \mathrm{SO}_{3}\right)_{2}$ である。なお，対アニオンの違いにより イオン伝導度に大きな違いは見られないことから，この ような塩濃度では電解液中のイオン構造に大きな違いは ないものと考えられる。

図 2 には, $0.5 \mathrm{M}$ の $\mathrm{Mg}\left(\mathrm{CF}_{3} \mathrm{SO}_{3}\right)_{2}$ を含む $\mathrm{DMF}$ 中で, $0 \mathrm{~V} \sim-4 \mathrm{~V}\left(v s . \mathrm{Ag} / \mathrm{Ag}^{+}\right)$の範囲で電位を走査したとき の $\mathrm{Mg}$ 電極のサイクリックボルタモグラムを示す。 約 $-3.3 \mathrm{~V}$ に観測されたカソード電流ピークは金属 $\mathrm{Mg}$ または Mg 含有化合物の生成を示唆し,アノード電流 は析出金属 $\mathrm{Mg}$ の溶解を示している。電解液の含水量 が約 $1800 \mathrm{ppm}$ の場合(図 1 (a)), Mg の溶解が始まる電 位はサイクルを繰り返すにつれて徐々に高電位側にシフ トした。これはカソード基板上に析出した $\mathrm{Mg}$ が電解 液中の水と反応してその表面に不動態皮膜が生成したた めであると考えられる。一方，図1(b)に示したように， 電解液の含水量が約 $170 \mathrm{ppm}$ の場合, サイクルを繰り 返しても溶解の始まる電位はほとんど変化しないばかり でなく, Mg 析出を示すカソードピークは徐々に増加す る傾向にあった。他の電解質塩 $\left(\mathrm{Mg}\left(\mathrm{ClO}_{4}\right)_{2}\right.$, $\left.\mathrm{Mg}\left[\left(\mathrm{CF}_{3} \mathrm{SO}_{2}\right)_{2} \mathrm{~N}\right]_{2}\right)$ についても同様の $\mathrm{CV}$ 測定を行っ た。両電解質塩ともカソードピークはー $4 \mathrm{~V}$ 付近までシ フトし, アノード溶解の始まる電位も図 1 (a) と比較して かなり高電位側にシフトし, 析出物の完全な溶解は起こ りにくいと考えられた。また，その場合，電位走査をく (a) Water content : ca. 1800 ppm

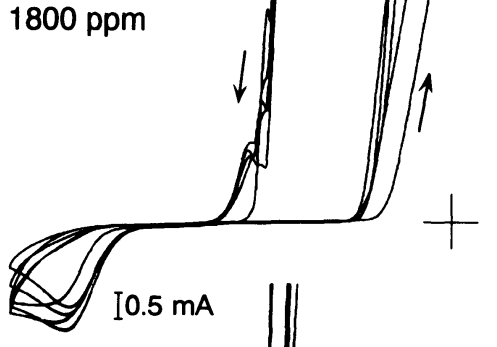

(b)Water content : ca. $170 \mathrm{ppm}$

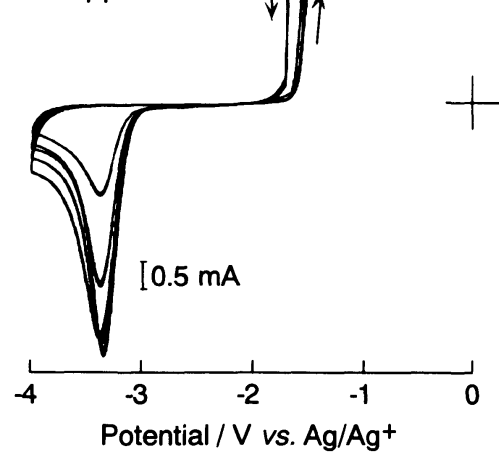

Fig. 2 Cyclic voltammograms for $\mathrm{Mg}$ electrode in $\mathrm{DMF}$ containing $0.5 \mathrm{~mol} \mathrm{dm}^{-3} \mathrm{Mg}\left(\mathrm{CF}_{3} \mathrm{SO}_{3}\right)_{2}$.

Scan rate $: 0.01 \mathrm{~V} / \mathrm{s}$

り返すにつれカソード電流ピークも減少した。

以上のことから, 金属 $\mathrm{Mg}$ のカソード析出は清净な カソード基板上, すなわち先に析出した $\mathrm{Mg}$ が完全に 溶解するような条件下でのみ可能であるということがわ かった。

(Received June 25, 1999 ; Accepted July 12, 1999)

\section{文献}

1) J. H. Connor, W. E. Reid, Jr., and D. B. Wood ; J. Electrochem. Soc., 104, 38 (1957)

2 ) J. D. Genders and D. Pletcher ; J. Electroanal. Chem., 199, 93 (1986)

3 ) L. P. Lossius and F. Emmenegger ; Electrichim. Acta, 41, 445 (1996)

4 ）松田好晴, 藤井俊茂, 吉本信子, 森田昌行, 芳賀正記 ; 表面技 術, 43, 36 (1992)

5 ）松田好晴, 今橋健二, 吉本信子, 森田昌行, 芳賀正記；表面技 術, 44, 672 (1993)

6) N. Yoshimoto, O. Shinoura, H. Miyauchi, M. Ishikawa and Y. Matsuda ; Denki Kagaku, 62, 982 (1994)

7 ) Y. Matsuda, M. Yamatani, N. Yoshimoto, M. Morita, M. Ishikawa and M. Haga ; J. Surf. Finish. Soc. Jpn., 46, 121 (1995) 